\title{
Media and cultural representation: The symbolic appropriation of identity in West African Screen Media
}

\author{
Noufou OUEDRAOGO, Research Assistant
}

Ibn Haldun University, Turkey

noufou.ouedraogo@ibnhaldun.edu.tr

o.noufou@ymail.com

\begin{abstract}
This article explores the portrayal of cultural identity in West African screen media, especially through television, cinema and visual advertising. It is exclusively an exploratory research which demonstrates that African cultural identity is essentially linked to its language, art, music, sculpture, as well as the use of local symbols. Hence, this study - which applies in essence a qualitative research design - is conducted in order to better understand the strategy of cultural depiction on West African media screens. As a result, the main objective is to demonstrate that national televisions and cinema really promote cultural identity in West Africa via visual symbolism. Consequently, the current study goes beyond the field of culture and identity to include the multidisciplinary domain of semiotics and visual communication. In fact, the investigations help to clearly understand how cultural identity can be delicately portrayed through the means of visual communication media. Therefore, while this study tends to comprehend the portrayal of cultural identity on West African media screens (Cinema and TV), the research attempts to establish a nexus between culture and globalization before discussing respectively the notions of local languages and identity, as well as the appropriation of cultural symbols via West African TV, cinema and advertising. Also, taking into account the cultural and linguistic diversities through a concrete case study, the analysis focuses specifically on three West African countries (Ghana, Burkina Faso and Mali); which TV sets are well-designed with visual symbols to reflect local identities.
\end{abstract}

Keywords: Culture, Identity, Screen media, Visual symbolism, West Africa. 


\section{Introduction}

As the anthropologist Edward Hall claimed in 1977, every strategy of communication brings about a cultural identity and every cultural representation is also a form of communication. However, the notions of culture and identity evolve over times and spaces. The technological changes have profoundly transformed the ways societies portray their culture and identity in media. With the advent of photography, visual images have replaced the traditional way of depicting cultural symbolism; because the imagery has been progressively used in the fields of communication, information, instruction, advertising, entertainment, medical diagnostics, etc. just to name few. This state of fact move the visual symbols from artistic symbols and aesthetic representations into the realm of indispensable media communication elements (Barnes, 2017).

In media communication, the cultural identity is always portrayed diversely according to the type of media. In TV for instance, the spectacle of televised information with its quasi-religious rituals has in itself become a commodity for which the daily news is only the material-pretext for its consumption. Hence; cultural symbols on TV screens turn out to be a sort of food fetishization. The spectators swallow the news like meals along with the cultural symbols softly diluted through various visual elements such as colour, music, clothes and of course the language. As a matter of fact, in West African national televisions (RTI in Ivory Coast, RTB in Burkina Faso, ORTM in Mali, Ghana Global TV, etc.) $80 \%$ of the TV programs are diffused in foreign languages. Actually, TV news works metaphorically like a kitchen with its artistic design of mixing ingredients, set of dishes cooked from recipes like TV series, served at real meal times by some great chefs, with its menu and customary rituals.

In addition, TV programs are always nurtured by floods of advertisings. Correspondingly, culture is also portrayed in advertising mechanisms. The conjunction of notions of culture and advertising has become, in information and communication sciences, a central notion, and therefore unavoidable (Charaudeau, 2001). Their subtle combination is nowadays part of the advertising strategy of advertisers. In fact, the cultural identity of a specific society means that it identifies itself with a cultural community and thereby intends to defend its affiliations: language, traditions, values, interests of a specific community (Galisson, 1991). 
Furthermore, we cannot talk about cultural identity without discussing the questions of linguistic appropriation. In West Africa specifically, most African constitutions have included the preservation of local languages very late. In Gabon, for example, it was notably in 1983 that the government tried to give new impetus to attempts at linguistic protection. In 2004, with the Ouagadougou speech in Burkina Faso, this imperative to preserve local languages was reiterated. Yet, until now local languages are not taught, at least as part of so-called "official" education, in West Africa. However, some major obstacles still thwart the introduction of local languages at school in West Africa. Indeed, to be able to navigate the education system, one must belong to an upper class, which is of course not the case for the vast majority of the population. Another problem concerns the multiplicity of languages which constitutes a brake on their teaching. Thus, it can be very difficult to decide on the priority given to a language to the detriment of another one. In some countries the choice is made in favour of a 'few majority'. However, this choice cannot be considered consensual. Whenever one language is privileged, it risks being privileged to the detriment of other languages; creating de facto a danger of unfair ethnic representation.

Correspondingly, referring to the theory of semiotics, it is possible to affirm that West African national televisions and cinema strongly contribute to the promotion of African identity through visual symbolism. Actually, one of the prime roles of semiotics is to reveal, explain, even interpret, the meanings of visual symbolism. This works throughout every field of knowledge such as: communication, anthropology, culture, arts, linguistic, sociology, civilization, etc. Hence, visual symbolism puts emphasis on the abstract form of the subject (the represented object) and then process by shedding light on "the constituent of the signified" (Beyaert-Geslin, 2006).

While this study tends to comprehend the portrayal of cultural identity on West African Screens (Cinema and TV), I will establish a nexus between culture and globalization before discussing respectively the notions of local languages, identity and globalization, as well as the appropriation of cultural symbols via West African TV, cinema and advertising. 


\section{Hegemony of Western culture in Western Africa}

The globalization and digitalization of the world have seriously affected African cultures and constitute a threat to their identities. Today, the United States of America, and to a lesser extent the European Union, impose their ideologies and cultural habits to African countries. This is perceptible in various fields such as sciences, army, industry or agriculture and of course in the domain the media with movies and TV series. In fine, this is not only an economic and political domination, but also and over-all a cultural and ideological hegemony. As a matter of fact, Americans, mainly, broadcast their films, books and songs all over the world, and more specifically on African continent. Even Western lifestyle has profoundly affected African people's habits: their ways of dressing, the sector of restauration, the foreign games replaced local games and traditional sports, etc. In doing so, more and more West African cinema rooms, for example, are now showing Western films whose main themes are foreign lifestyles, habits, customs, and values. Thus, Western countries successfully imposed their culture which, step by step, dethrones the traditional cultures of the majority of African countries.

More interestingly, in West Africa, cultural policies are in difficulty; given the little interest that decision-makers have in them - from the education, communication, sciences and technology domains - culture can be revalued and be fully at the service of the development of the African continent (Henry; Kossou, 1985: 139-142). Nonetheless, West African cultural richness is immense. In the field of art, in particular, African music is at the source of jazz or reggae. Literature is also rich and diverse, as are dance, painting, sculpture and cinema. But African films have great difficulty in establishing themselves against western productions. African culture therefore deserves neither ignorance nor contempt, but valorisation. Also, it needs the support of Western countries - in particular France which intervenes a lot in cultural productions - in order to continue to develop, or quite simply to exist. But can financial assistance and technical support from western countries be enough to keep traditional arts, crafts and industry alive? Obviously not; because when two cultures collide, the strongest wins the battle. Therefore, all the local knowledge, ideas and artistic achievements (dance, theatre, cinema, literature, music...) should be developed and valorised by African experts themselves in order to influence the rest of the world. 
Nevertheless, despite the abovementioned factors, African cultural identity is expressed through contemporary art some West African countries. For example Ivory Coast (Côte d'Ivoire) promotes its local cultural identity through "Le Marché des Arts et du Divertissement d'Abidjan" - which means approximately 'Abidjan Arts and Entertainment Market' - with new innovations introduced in 2018 after a few years of hiatus. Hence, professionals promote African music, dance, and theatre in Abidjan. Also, the capital city of Senegalese, Dakar, organizes regularly "Dak'Art" for the promotion of visual arts, including contemporary art, poetry, literature and music. A similar event takes place in the economic capital of Cameroon called "the Doual'Art" where African artists use to perform on the streets of Douala.

\section{West African identity is victim of globalization}

In this age of economic and cultural globalization, major changes are taking place within African societies, leading to multifaceted crises, including those of identities. While these realities are less pronounced in the West and in other parts of the world, they are particularly acute in West Africa, where several constraints (political, economic and social) are a brake on the full development of the cultural sector. However, West Africa is at a crossroads and faces major changes such as: socio-political instabilities, economic crises, civil wars, terrorism, the rise of religious extremism, social unrest, Western hegemonies, upheavals of educational institutions, family instabilities, poverty, epidemics, cybernetic piracy, global warming, etc. just to name few. These situations worsen the identity crisis that West African countries are already facing. To illustrate it, the destruction of tangible and intangible heritage like the mausoleums of Timbuktu in Mali, the loss of the linguistic values of the communities, the deliberate destruction of places of memory, the violation of the cultural rights of individuals and communities, the disregard of the principles of democracy, the contempt for cultural freedoms, etc. are constant and consistent indicators of a cultural identity crisis in West Africa.

However, the scholars Paul-Marc Henry and Basile Kossou (1985: 132-133) noted that African intellectuals tried, after their independence, to give importance to the notion of African cultures rather than "cultural identity". This, however, sounds awkward for the researchers: 
It can no longer be appropriate to indulge sterilely in African cultures, by freely asserting their value and their quality, thus cultivating an ego that hardly admits that it no longer belongs to itself completely; nor should it be a matter of simply speculating on these cultural values, withdrawing them from the social reality which gives them their full meaning (Henry; Kossou, 1985: 132-133).

This is a major precision that makes African cultural realities intrinsically linked to the social practices of the people who observe them. Nevertheless, we must rectify the situation that, in contemporary discourses on Africa, particular emphasis is increasingly placed on the questions of post-colonialism, civic education, African cultural emancipation, women emancipations, etc. From this perspective, it seems obvious, regarding the above-mentioned facts, to work through a variety of reflective tools in order to shed light on the issue of African development through the variable crisis of cultural identity. Hence, language, sciences, arts, philosophy, technology, humanities and other expertise are invited to this debate, where the social facts mentioned will be approached from various angles.

\section{Linguistic identity and globalization in Africa: a cultural dilemma}

In one of his academic researches, the linguist and Anthropologist Clinton Robinson (2019) ${ }^{1}$ wondered why the language issue is so important for development in Africa. In fact, there are many local languages in Africa: 400 in Nigeria, 250 in Cameroon, 63 in Burkina Faso, 65 in Ivory Coast, around 60 in Ghana, etc. And yet, the vast majority of the education is carried through the languages of the colonial era: English and French. The use of the language in education in West Africa is structured according to the practice instituted by colonial administrations. However, there are attempts at change aiming to introduce local languages into the educational system.

More importantly, when the African local language is absent from the educational system, the linguistic identity cannot be used as a vehicle for world discovery, structured analysis or intellectual evolution. This means that the African students will never discover the grammatical,

\footnotetext{
${ }^{1}$ Robinson, C., Vũ, T.A.T. Literacy, languages and development in Africa: a policy perspective. Int Rev Educ 65, 443-470 (2019). https://doi.org/10.1007/s11159-019-09785-2
} 
phonological, lexical structures of their own languages because these languages are not part of instructive system. In European countries and in almost every developed country in the world, the local language of the learner is always part of learning process. According to Clinton Robinson (2019), the blockage is political. Indeed, governments sometimes see multilingualism as a problem to be managed and not as a network of languages which allows real communication between populations.

Moreover, the development is above all a learning process because there is no learning without communication, without language, without culture. Hence, language plays a primordial role in essential and fundamental aspects of development: communication, human relations, negotiation between institutions, culture, critical analysis which is a language activity, etc. As far as development is concerned, there are obviously some impacts, in particular the separation between the local lifestyle activities and the theoretical world of learning process which is a copy of western system. In other words, what happens at school is not practically linked through a language to what happens concretely at home. This creates a serious mismatch between theory and practice (Clinton, 2019).

Notwithstanding, it is above all a question of not locking a population in a "linguistic ghetto" which would restrict itself to a language used only very locally (ibid, 2029). Access to other languages is therefore necessary and essential for social development. But by promoting a total openness to the world through foreign languages, West African societies risk falling into the other extreme: some of them start to scorn and despise the local languages and culture. In this situation, the local language must be valued and taught according to its popularity. In such situation, the appropriate thing to do is to implement a fundamentally multilingual approach in teaching both foreign and local languages at school; so that the linguistic practice of the community is reflected in the linguistic structure of the education. As an illustration, In Democratic Republic of Congo, three languages were used at school in years 2000s: the local language Baka, the regional language Lingala spoken in seven different countries, and French which is the official language of the country. 


\section{Research methodology}

This study is exclusively an exploratory research which aims at investigating the portrayal of cultural identity in West African media screens, especially through television and cinema. This African cultural identity is essentially linked to language, art, music, sculpture, as well as local symbols. Hence, this study - which applies in essence a qualitative research design - is conducted in order to better understand of the strategy of cultural depiction on West African screens. For this purpose, the fundamental question that guides the current study is the following: how do West African cinema and television constitute a vehicle of indigenous culture and local identity? As a result, the main objective is to demonstrate that national televisions and cinema really promote cultural identity in West Africa via visual symbolism.

In terms of visual symbolism, it is appropriate to refer to semiotics in order to full decipher these technical concepts. Commonly, we refer to the notions of 'symbols and signs' under the broad denominator of 'symbolism'. Actually, in visual communication, symbolism represents the basic concept of subject matter. Discussing about cultural identity, the use of symbols has changed over times. In visual art, the symbol is persuasive, energizing and attractive. As a result, in order to be effective, it contains a locutionary act, an illocutionary act and a perlocutionary act (Austin, 1962). This refers to the Speech Act theory developed by the British linguist John Langshaw Austin in 1962. The figure 1 below illustrates it more clearly:

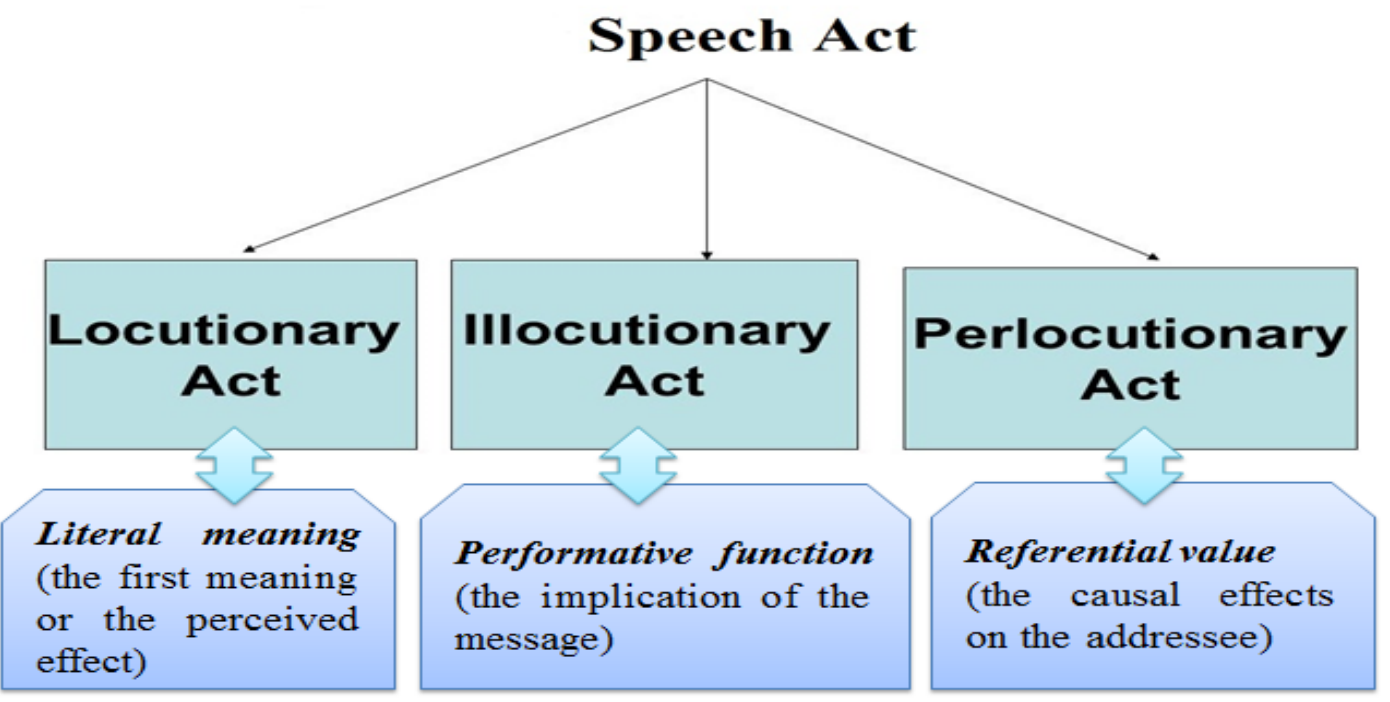

Figure 1: The Speech Act theory (John L. Austin, 1962). 
However, in this digital era, the portrayal of contemporary symbols is quite different. In order to meaningfully depict visual elements (graphics, paintings, images, etc.) on digital screens, savvy visual communicational strategies must be implemented. Thus, in this exploratory study I will resort to semiotics in order to analyse these visual symbols. In fact, the linguist Ferdinand de Saussure - considered as the pioneer of this field of study - has defined semiotics as the study of languages, signs, symbols and their meanings.

In addition, semiotic notions such as semantic differential, encoding, decoding, connotation and denotation, as well as signifier and signified, should also be applied to the deciphering process before understanding the implications of visual symbols in media. Thus, Signs and symbols can be used to help viewers understand the local identity. For example, traditional symbols and local signs can be well-designed to allow both literate and illiterate populations re-appropriate their local identity. Actually, visual symbols are able to represent perfectly concepts of actual objects because they shift from concrete objects (denotation) to abstract signs (connotation). Consequently, it is imperative to refer to semiotics to elucidate the implications of visual symbols (textual, verbal, text-images, text-sculptures, or text-plans, architects, etc.). This entails to split up the represented objects into two main streams: signified and signifier. Signifier and signified are two paired sides of linguistic interpretations developed by Ferdinand de Saussure and later on discussed by the structuralist school (Hjelmslev, 1930). In fact, the signified is the original aspect of the subject. It is physically perceived and palpable by the five human senses. Nonetheless, the signifier refers to the conceptual, abstract and semantic connotation indicated by the visual symbols.

According to the pioneers of semiology (Ferdinand de Saussure: 1857-1913), semiology is a vast scientific field of which linguistics is an element. Roland Barthes, in the 1960s, reversed the proposition and founded the 'semiology of image' by borrowing its concepts from linguistics. It was undoubtedly the historical condition so that the image, as an object of study, could enter the academia. While Roland Barthes focused on the still images, Christian Metz was interested in cinema (the motion pictures). For the structuralist Lévi-Strauss, semiology postulates the object (text, image, film, etc.) as the main locus of meaning and language as the foundation of any sign system. Hence, the semiology of cinema puts emphasis on films in their linguistic dimension, as a system that produces meaning. Contextually, visual image analysis is useful in understanding 
visual communication mechanisms, culture and advertising in particular. As Geneviève Jacquinot (1985) underlines:

Many practices for analysing audio-visual messages have developed along the lines of theoretical work on the semiology of the still image (...) This type of educational exercise can become useless or even dangerous: when it aims more at terminological learning than methodological learning - we juggle with polysemy, monosemia, code, referent, signifier and signified - when it becomes a finality in itself instead of being a means of helping to see, hear, detect meaning. This, in turn, brings about different denotations and connotations when it is not relativized by the contribution of other knowledge on images: history of art, iconography, psychoanalytic, socio-historical, anthropological approaches, etc. Then it transforms into cultural or social imperialism to impose 'common sense' without respecting the complex processes of appropriating messages.

Notwithstanding, Rudolf Arnheim (1973), for his part, discussed the importance of global perception in the analysis of image. For him, the image does not accommodate the linearity of language and "visual thinking" is not the sum of its constituent parts. As real forms can be conceptualized, visual perceptions can also be "semiotized". In his semiotics, Peirce (1938) distinguishes three types of signs: index signs, iconic signs, and symbolic signs.

- Index signs: These are sensitive traces of a phenomenon, a direct expression of the thing manifested. The clue is related to the thing itself (the use of smoke for fire for example).

- Iconic signs: These are analogic representations detached from the objects or phenomena represented.

- Symbolic signs: These representations break all resemblance and all contiguity with the thing expressed. They concern all the arbitrary signs (linguistic, semantic, social codes, etc.).

For Daniel Bougnoux (1991), the passage from the index to the symbolic (from analogic to digital) would be the path of education and culture, while art, dreams and the imagination would follow an inverse path (from symbolic to index or from digital to analogic). 


\section{Case study: the portrayal of cultural symbols and identity on West African screens}

The portrayal of culture on screens (TV, Cinema, or digital screens) is made possible through the use of signs and symbols. In West African context, media experts and cineastes always use cultural symbols to indirectly depict their identity. These cultural symbols can be visual, graphic, sound, or pictorial elements that symbolically refer to a cultural identity, to a cultural appropriation. These visual depictions of cultural symbols in West African media are essentially perceptible through Cinema and national Televisions screens.

\section{A) West African cinema and cultural issues}

To begin with the domain of cinematography, Nigeria has become, in a few years, one of the ambassadors of West African cultural identity with Nollywood. In fact, while Nigerian scripts writers generally write in English, half of the films shot in Nigeria are shot in the local language Yoruba. This can allow some regional spectators like Beninese and Togolese, in particular, to watch them since it is also their national language.

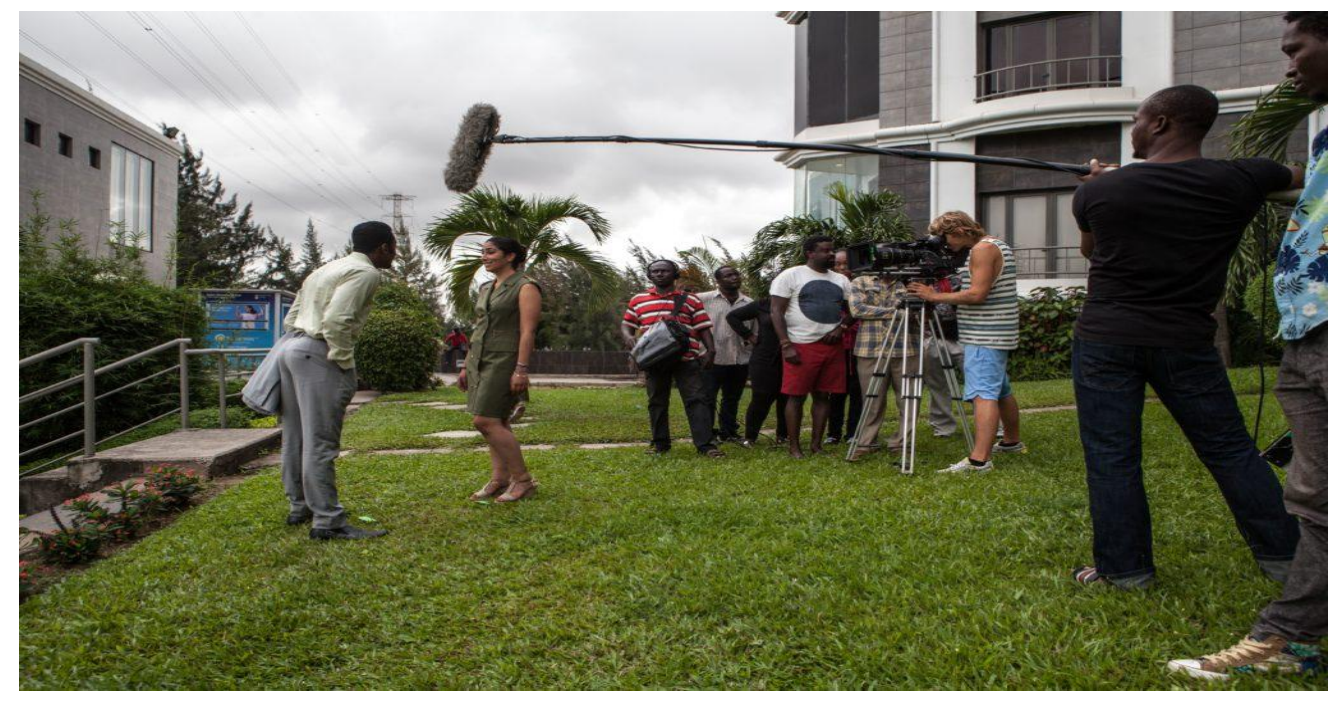

Figure 2: Shooting of the movie 'The CEO' in Lagos, Nigeria (Plaucheur-AFP, 2015).

In terms of cultural representation, Nigeria is incontestably at the epicentre represents today the first continental power. The cultural dynamism of the most populous country in Africa is depicted thousands of Nollywood movies every year. Though, the big majority is in low quality. 
In this regard, the expert of audio-visual and cinema at the International Organization of 'La Francophonie', Pierre Barrot ${ }^{2}$, pointed out that:

It is very interesting to approach this country through culture. The other ways to approach Nigeria are oil, the economy or Boko Haram; and it is not always the best way. The good side of Nigeria is the culture. We cannot say the opposite. In fact, Nigeria has become a cultural power (...) by developing a model of its own local identity that cannot be compared to any other. Ultimately, they have been imitated. What Nigerians did from the 90s with Nollywood and the phenomenon of distributing films directly to the public via video, is Netflix today (Barrot; Ibbo, 2005).

Like the United States, on a global scale, Nigerians have conquered their African identity for decades with their visual symbols, music, literature and (contemporary) art. This phenomenon is not new, but it is even more palpable today. In 2015, according to the Unesco statistics, Nigeria was among the biggest producers of films (those who have produced more than 100 works). More importantly, a few years earlier, in 2009, Nollywood dethroned Hollywood as the second largest film industry in the world. The downside is, however, the quality of productions. The entire Nigerian production, mostly in video format, is not considered to be up to international film standards.

Nonetheless, apart from cinema, Nigeria is also experiencing an explosion of creativity in the visual arts. In 2018, in London, a portrait painted by the Nigerian sculptor Ben Ewonwu, known as "the African Mona Lisa", was sold for 1.3 million euros at an auction. This national masterpiece was considered a pride for West African cultural heritage.

Apart from Nigeria, another West African country which promotes cultural identity through cinema is obviously Burkina Faso with FESPACO ${ }^{3}$. Every two years, Ouagadougou, the capital city of Burkina Faso, hosts one of the greatest African cultural events called FESPACO: Pan-

\footnotetext{
${ }^{2}$ Pierre Barrot coordinated the collective work entitled 'Nollywood, the phenomenon video in Nigeria'; wrote with Ibbo Daddy Abdoulaye in 2005.

${ }^{3}$ FESPACO (Panafrican Film and Television Festival of Ouagadougou) is a film festival in Burkina Faso, held biennially in the capital city Ouagadougou, where the organization is based. FESPACO, in French, is the shortened form of Festival Panafricain du Cinéma et de la télévision de Ouagadougou. Online Access at: https://fespaco.bff.
} 
African Film and Television Festival of Ouagadougou. Created in 1969 under the name "First African Film Festival of Ouagadougou', the FESPACO has gradually established itself as an essential showcase for African films and all audio-visual professionals on the continent.

Initially, FESPACO was created to portray the realities of African culture and identity through movies' screens since 1972. Over the years, other goals have been added to the first. Today, FESPACO's mission is to promote and foster the dissemination of all works of African cinema inside and outside African continent. It is a favourable vitrine for exchanges between audiovisual professionals, artists and cultural experts. It also contributes to the socio-economic growth, the cultural development and the preservation of African identity.

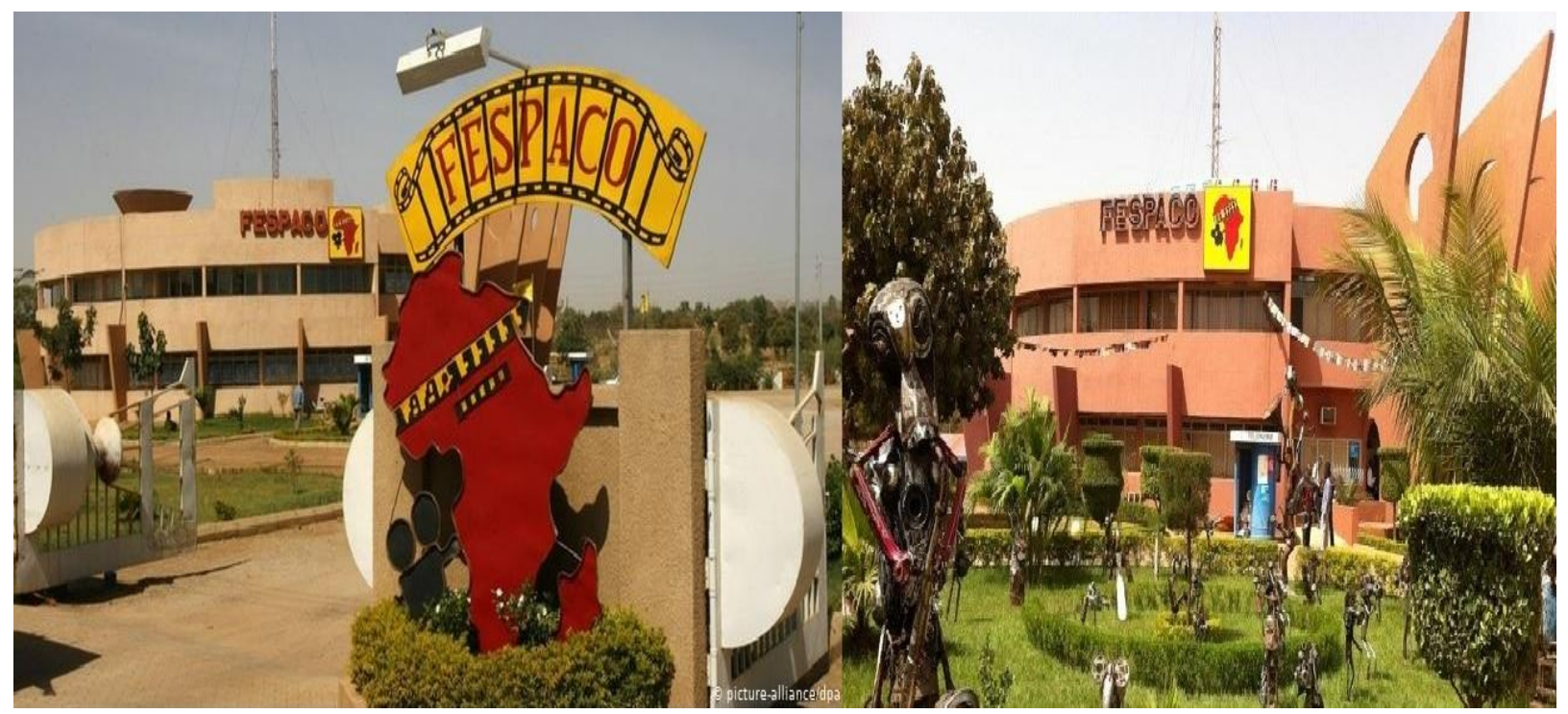

Figure 3: The headquarters of FESPACO in Ouagadougou, Burkina Faso.

Thus, FESPACO is a framework for meetings used to promote the development of African cinematography. After that of the first edition in 1969, visual symbols have been associated to each edition in order to depict the African realities. Moreover, the general theme of the sessions is chosen taking into account the concerns of Africa and the role that African cinema must play in raising the awareness of African peoples. From this perspective, the theme must be understood as a reflection on the concerns of our time and not a criterion for competition. Hence, artistic 
meetings and cultural discussions over the years have strongly contributed to the affirmation of the African identity ${ }^{4}$.

Additionally, in 2019, during the $50^{\text {th }}$ anniversary of FESPACO, a traditional parade was organized by the promotors to magnify African cultural identity with aboriginal choreography and body painting that reflect local symbols. See the picture (figure 4) below.

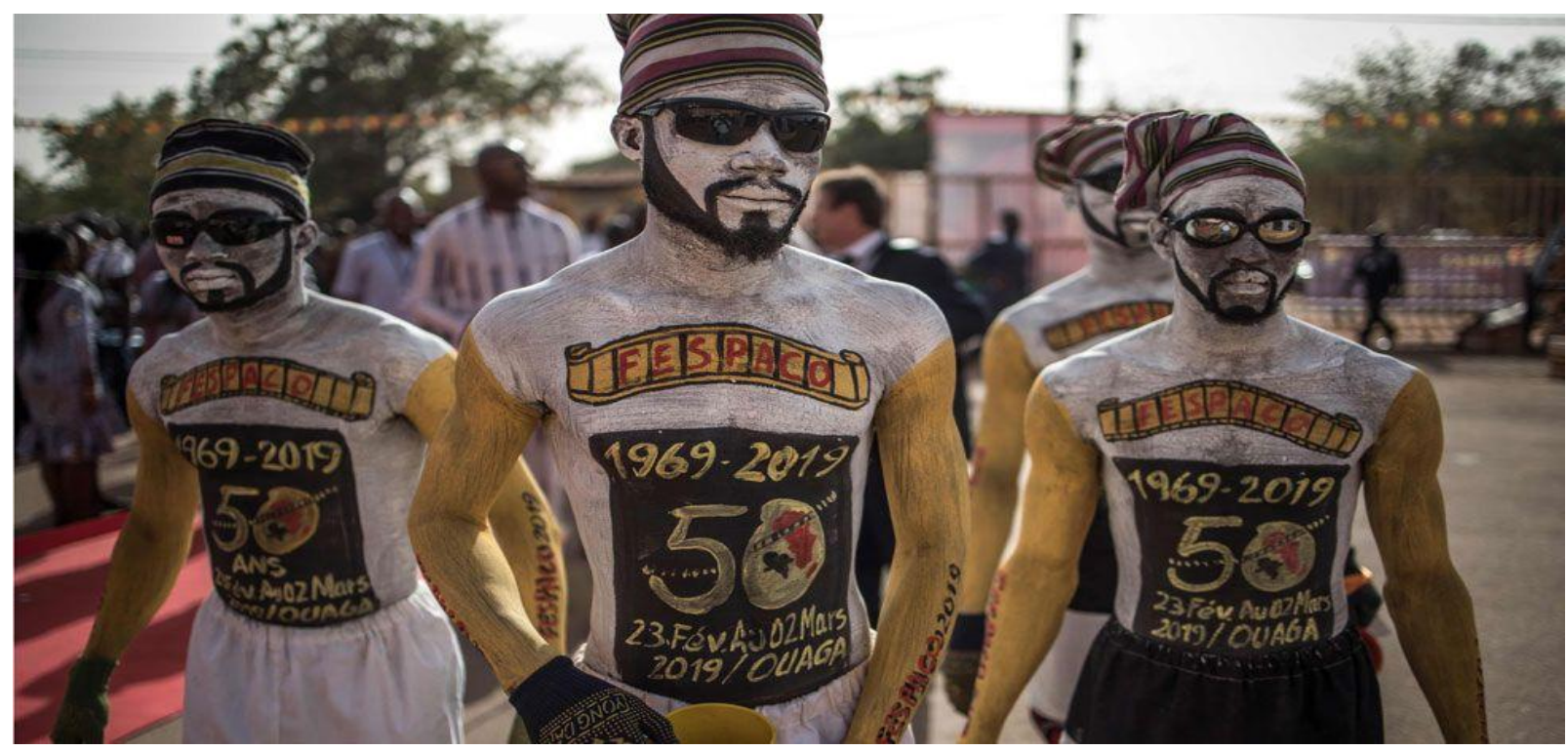

Figure 4: Body painting during the traditional parade of the $50^{\text {th }}$ anniversary of FESPACO.

Thirty years earlier, in 1989, during the commemorative event of FESPACO's twentieth anniversary, another similar organization was created to promote African audio-visual productions: African Film Library of Ouagadougou. It was created by African scripts' writers, filmmakers and media professionals who have been discussing about it since 1973 through seminars, symposiums, professional meetings and conferences. This 'African Film Library' is looking forwards to promoting and safeguarding African film heritage as well as African cultural identity through cinematographic productions.

\footnotetext{
${ }^{4}$ The various visual symbols of FESPACO during its fifty years of existence: from 1969 to 2019. Online Access link to the YouTube Channel:

https://www.youtube.com/watch?v=UVqH2oxx7AM\&feature $=e m b \_l o g o \& a b \_$channel=FESPACO.
} 


\section{B) Cultural representation in West African national Televisions}

Although almost all of West African national Television channels are broadcasting in foreign languages (English or French), most of the TV sets are well-designed with visual symbols which reflect local identities. And so do some sound tracks. For the matter of illustrations I will focus on three West African countries taking into account the cultural and linguistic diversities: Ghana, Burkina Faso and Mali.

Despite the fact that the majority of Ghanaian citizens prefer communicating in local dialects rather than English, the national TV - the Ghana Broadcasting Corporation (GBC or GTV) give the major daily news in 'the language of colonization' (English). Nonetheless, the TV set displays some local concepts and cultural symbols that portray the Ghanaian identity. Actually, before hosting the news, the jingle is composed of visual elements and a stimulating music soundtrack well-orchestrated in order to catch the attention of the viewers. Indeed, it begins with a very captivating message written in capital letters: "GTV: THE PULSE OF THE NATION", followed by a powerful local sound playing in crescendo.
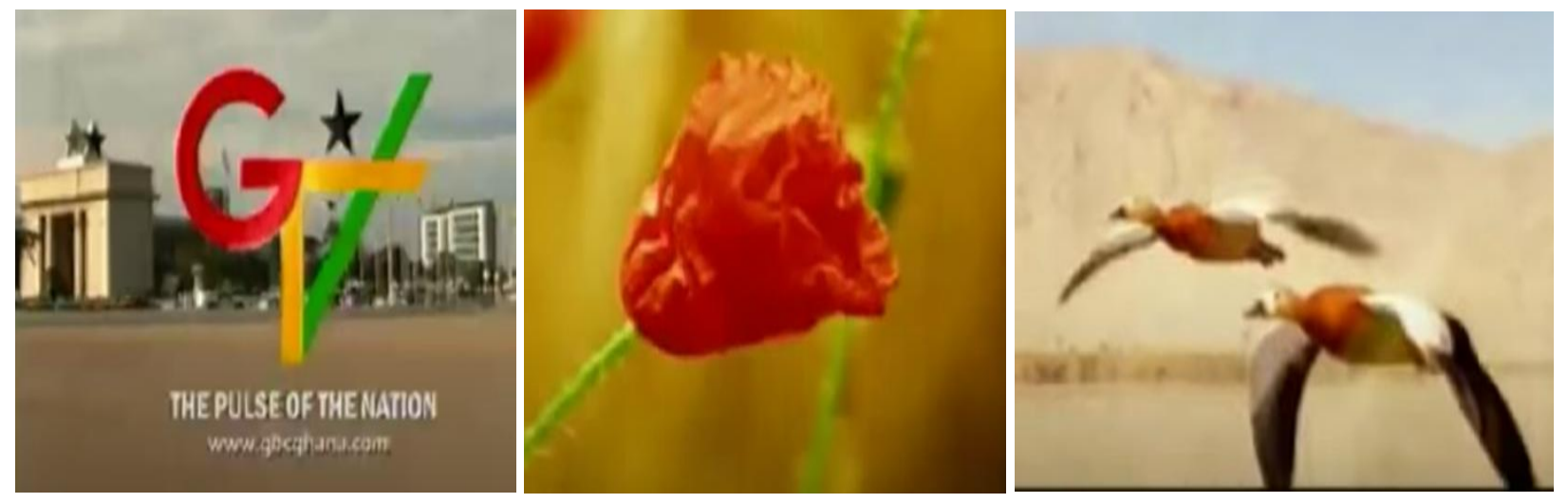

Figure 5: Visual symbolism from Ghana Broadcasting Corporation (GTV).

In order to clarify the connotations of the jingle, full of visual symbols, we can refer to semiotics. Hence, the use of a close-up shot to frame a red opening flower intends to centralize the viewers' attention to a sensation of hospitality, prosperity and love; while the flying birds symbolize the notion of freedom. Furthermore, the colours of the logo (red, yellow, green and black star)

\footnotetext{
${ }^{5}$ Ghana Television (GTV); the Official YouTube Channel's access link is the following: https://www.youtube.com/watch?v=9CIxmGO0310\&ab channel=GhanaBroadcastingCorporation
} 
symbolize the colours of the Ghanaian national flag. Other visual symbolisms such as the sky and the waterfalls, connotations of divine providence, have also been associated. In less than one minute, all these artistic components and visual symbols have been purposely used in order to attract the audience's attentions about their cultural heritages.

Put it differently, the Burkinabe national Television channel's (RTB) ${ }^{6}$ set is also well-designed with visual local symbols that are always showed before hosting the news. In the visual elements below we can see different cultural and local symbolisms which represent the country's national identity.

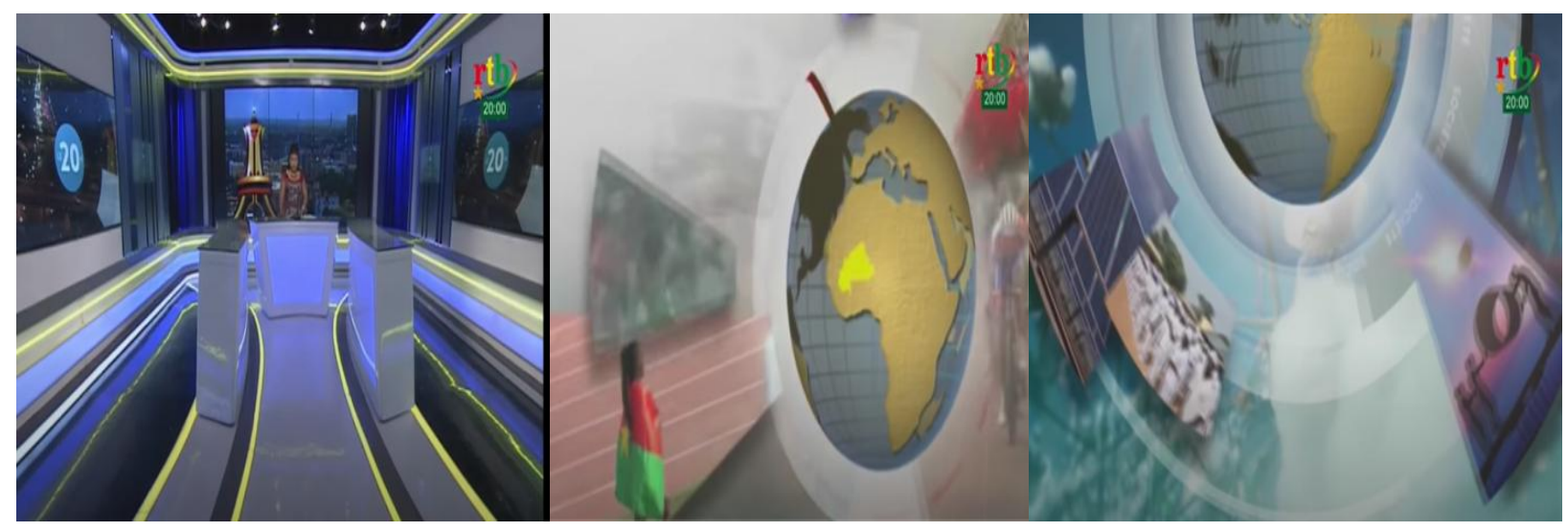

Figure 6: Visual symbolism from Burkina Faso National Television (RTB).

From left to right, we can see in the first image a memorial displayed behind the journalist. This memorial is called "Le Monument des Héros Nationaux", which means the memorial of national heroes. Located at 500 metres from the presidential palace, this monument is considered as a temple of memory for local populations. It represents a remembrance of emblematic historical fights in the collective memory of the Burkinabe. The second picture tends to promote the national sports by showing an athlete with the national flag of Burkina Faso and a cyclist coming just behind the globe as to say "Burkina Faso is coming!". As for the third image, it displays traditional festivals, cultural events, and national resources of Burkina Faso. Thus, in only 15 seconds before the news, all these visual symbols are scrolled to the tele-spectators of the national television.

\footnotetext{
${ }^{6}$ RTB: The Burkinabe National Television's official YouTube Channel. Online Access link: https://www.youtube.com/watch?v=qbpSqt7OgmU\&t=6s\&ab_channel=RTBRadiodiffusionT\%C3\%A91\%C3\%A9visionduBurkina.
} 
Finally, the Mali national television (ORTM) ${ }^{7}$ also uses visual symbols to depict the country's local culture and identity. This state of fact is perceptible through the visual elements below (figure 5).

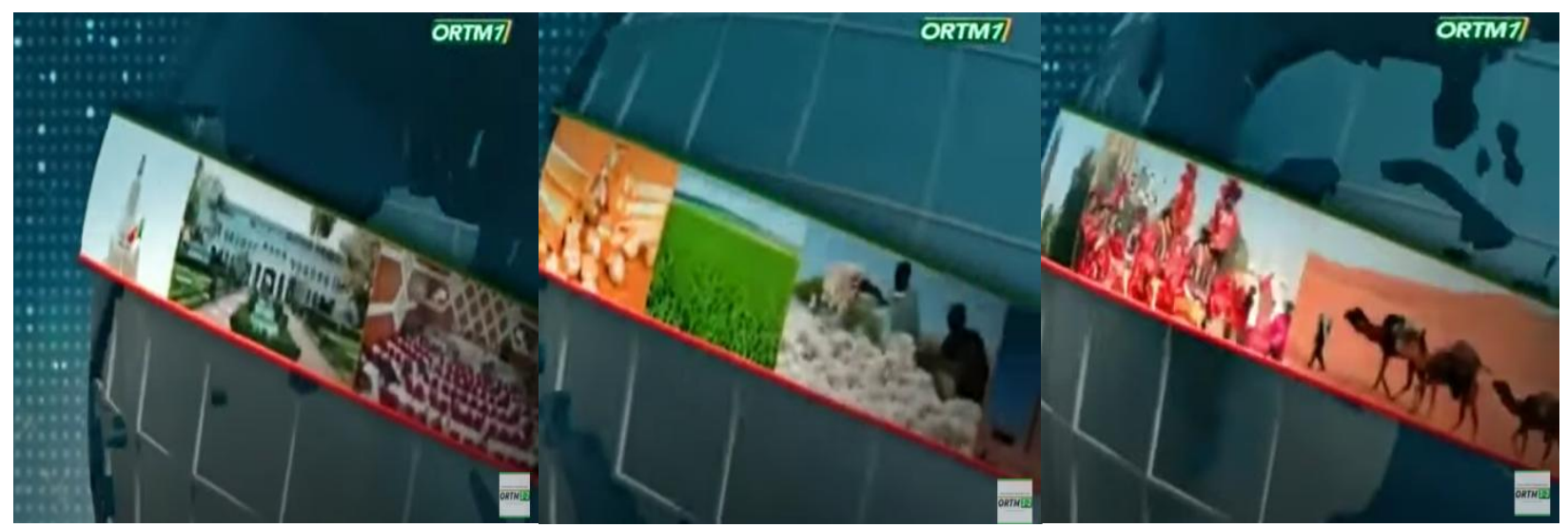

Figure 7: Visual symbolism from The Mali National Television (ORTM).

First of all, before the general news it starts by scrolling the images of the national flag, the presidential palace of Koulouba, and a cultural site for tourists. The second visual element contains some mineral resources (gold namely) and the agricultural potentialities (cotton). The last visual at right side shows a traditional festival (full of local colours and traditional clothes) and some horses in the desert which represent the means of transportation for local populations. All these cultural depictions can only be seen in less than 15 seconds before the presentation of the general news on ORTM.

As we can see through these three examples of West African national televisions, the African cultural identity is softly (and intentionally) portrayed on TV screens. However, since TV programs are always full of advertising, we cannot talk about the portrayal of cultural identity on television without having a glance at the representation of culture in advertising. This is what I will discuss in the following lines.

\footnotetext{
${ }^{7}$ ORTM: The Official YouTube Channel of the Mali National Television: https://www.youtube.com/watch?v=gOkz8eW6nxQ\&ab_channel=ORTM1-2
} 


\section{Ways of depicting cultural identity in visual advertising}

Visual advertising is one of the media communication instruments which are very much privileged by marketers in this digital era. Indeed, visual advertising is a form of mass communication, the purpose of which is to focus the attention of the public (the viewers) on visual elements such as graphic, colours or images, etc. In fact, it is not only limited to the marketing of products, goods or services; but also to the promotion of cultural identity. The cultural features associated to visual advertising are purely expressed through visual symbolism (Hall, 1977).

Actually, in visual advertising strategies, the cultural concept of identity is understood in a sociological sense. It refers to a social group's way of life: as well as their ways of feeling, thinking, or acting. In doing so, it entails sociocultural representations, aboriginal behaviours, and socioemotional attitudes symbolized by index, iconic, and symbolic signs (Peirce (1938). All the same, in visual advertising, the use of the local symbols, traditional images, indigenous labels, historical narratives and aboriginal myths, etc. tends to give to the collective consciousness a sort of re-appropriation of its personality, its local identity and its historical unity (Balibar, 1994: pp.53-54).

Moreover, visual advertising is a kind of marketing of local image though visual symbolism. More specifically, advertisers are looking forwards to strategically portraying a constructive and

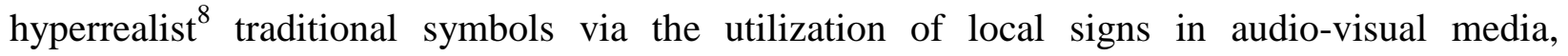
magazines and posters (Kotler, 1931; Baudrillard, 1981). Subsequently, visual advertising intrinsically linked to the sociocultural allusions and cultural identities that it portrays. For example, a visual advertising made in West Africa, whatever the purpose, will always be different from another one in a Scandinavian country, which will also be different from a Latin American one, or a Chinese one, and so forth.

Put it in a different angle of view, visual advertising gives the impression of cultural engine, a cultural regulator, and a social mirror at the same time (Cathelat, 2001). In this context of globalization marked by the opening of transnational markets, the process of digitalization and

\footnotetext{
${ }^{8}$ Jean Baudrillard (1929-2007) was a French cultural theorist, philosopher, and sociologist. His imaginary concepts of "hyperreality" and "simulacrum" have strongly influenced sociological, philosophical and communicational theories; especially in the domain of media, visual communication and popular culture.
} 
the intensification of international trades as well as the expansion of digital media, the diffusion and circulation of local goods and products as well as cultural identities models and values has been alleviated (Guidère, 2008: P.114). In such a context of digitalization of media outlets, visual advertising is turning out to be more and more a vehicle that transports visual symbols, multilingual products, local cryptographs and cultural identities. Indeed, amongst the cultural elements enclosed in visual advertising, the sociocultural aspect occupies a vital position because it contains all the social habits, traditions, beliefs, local values, and rules of conduct (norms, religion, morals, ethical standards, etc.).

Ultimately, visual advertising, as does any type of media advertising, plays overall on cultural identities that have already been consecrated to the needs of specific social groups. That is why John Berger stated that a reality in visual communication is a social construction (1990). In visual communication, the colourful photographs, the powerful messages and cultural slogans, the images of celebrity, slangs, local concepts and cultural symbols are most often reinforced by dynamic and influential local sound tracks that transport the spectators into a hyper-realistic world, a dreaming world (Baudrillard, 1981). These visual constituents have been deliberately included in the advertisements with elusive strategies in order to meet the audiences' desires.

To illustrate it in the West African context, there is a visual advertising studio in Burkina Faso called Stand Studio 9 , specialized in the creation of visual advertisements emphasizing artistic creations, linguistic appropriations, African history, values, culture and identity. In fact, these visual advertisings put emphasis on the persuasive nature and allusive cultural symbols (be it visual, or sound) in the aims of portraying a specific cultural identity. When it comes to creating an international visual advertising, the cultural identity should be more or less softly diluted through the use of visual symbolism. However, for local visual advertisings, the slogans, symbols and traditional sounds are much more powerful, explicit and very influential.

To sum up, the portrayal of cultural identity in visual advertising appears to be one of the effective visual communication strategies that can strengthen countries' soft power vis-à-vis the international community (Joseph Nye, 1990). Therefore, it seems appropriate to have a critical

\footnotetext{
${ }^{9} \mathrm{Km}$ Stan Studio' official YouTube Channel: https://www.youtube.com/watch?v=1vro3dzo$\underline{\mathrm{d} 8 \& \mathrm{ab} \_ \text {channel}=\text { KmStanStudio }}$
} 
look at the concept of cultural identity and the Professor Joseph Nye's notion of 'soft power' when it comes to discussing the questions of cultural identity in visual media communication.

\section{Conclusion}

Considering what I have discussed throughout this article, there is no doubt that the portrayal of cultural identity on West African screen media is made possible by the use of visual symbolism. Indeed, local cultural symbols are embedded in the way visual communication strategies are designed, softened and delicately elaborated. As does any kind of advertising, visual advertising turns out to be very effective in terms of depiction of cultural identity. Hence, with the advent of digitalization, visual symbols can straightforwardly move all over the world by captivating the attentions of the viewers. For the matter of illustrations, I investigated three West African countries (Ghana, Burkina Faso and Mali) taking into account their cultural and linguistic diversities. Yet, West African national Televisions are broadcasting either in English or in French but the TV sets are well-designed with visual symbols that reflect local identities.

Although the strategies may differ, the depiction of cultural identity in visual advertising is always entrenched in the subtle use of local symbols, ideologies, civilization and social beliefs (Hall, 1977). In a nutshell, the cultural values and local symbols, particular to every society, are strategically used to assure the success of identity transmission via visual media communication. Based on a theoretical framework about linguistic, semiotics, culture and identity appropriation in West Africa, I applied it to a concrete example of how cultural identity is portrayed through West African cinema and national television channels, as well as through visual advertising.

Swayed by sociocultural symbols, cultural identity and local realities, visual advertising strongly contributes to influencing viewers' mental perceptions and their social attitudes (Cottin, 2001). From this perspective, visual advertising bears not only a commercial function, but also and overall it is a vehicle that transports cultural identity. Thus, a dualistic relationship of cultural identity and commercial drives is then generated by visual advertising mechanisms. Accordingly, the visual representations of products or services overlap with cultural identity contained in local symbols. That is why Cathelat (2001) suggested considering the target viewers as "cultural targets and not as simple marketing target". 
Cultural identity can also be portrayed visual arts such as sculpture, drawing, calligraphy, and painting. For example, during the first Intifada in Palestine, which happened in 1987, the wellknown visual artist Sliman Mansour (1947) used his paintings and different visual artworks to portray the cultural notion of Sumud, which means "steadfastness" or even "political resistance" against Israeli oppression. Clearly, as we have seen all the way through this article, cultural identity can be successfully portrayed through the use of visual symbolism in cinema, televisions, visual advertising, as well as visual arts. 


\section{References}

Adam, J-M. \& Bonhomme, M., (1997). L'argumentation publicitaire, Rhétorique de l'éloge et de la persuasion. Paris, Nathan université.

Arrivé, M., (2007). À la recherche de Ferdinand de Saussure. Paris, PUF.

Balibar, E. (1994). Identité culturelle, identité nationale. In: Quaderni. $N^{\circ} 22$.

Baudrillard, J., (1996). La société de consommation (English : The Consumption Society). Paris, Edition Folio essais;

Bargh, A. \& Morsella, E. (2008). The Unconscious Mind of Sigmund Freud: Perspectives on Psychological Science. Yale University Press,

Barnes, S., (2017). An Introduction to Visual Communication. From Cave Art to Second Life ( $2^{\text {nd }}$ edition). Series: Visual Communication.

Barrot, P., Ibbo, D., (2005): Nollywood: The Video Phenomenon in Nigeria. Journal Article.

Barthes, R., (1964). Rhétorique de l'image, in Communication $\mathrm{N}^{\circ} 4$. Online Access : https://www.persee.fr/doc/comm_0588-8018_1964_num_4_1_1027.

Baudrillard, J., (1981). Simulacra and Simulations, Paris, France.

Beaud, B., \& Weber, F., (2010). Guide de l'enquête de terrain. Paris, La découverte, Collections Guides Grands Repères.

Berger, J. (1990). Ways of seeing, BBC Programme.

Beyaert, G., (2006). L'Image entre sens et signification. Paris, Publications de la Sorbonne.

Bordron, J., \& al., (1994). Approches sémiotiques sur Rothko. Nouveaux Actes sémiotiques, Limoges, PULIM.

Burnett, T., (2016). Primitive Culture: The origins of culture, Dover Edition,London.

Charaudeau, P., (2001). Langue, discours et identité culturelle. Revue de didactologie des langues-cultures 2001/3-4, $\mathrm{N}^{\circ} 123$.

Claude, J., (1992). L'enquête par questionnaire, Manuel à l'usage du praticien. Bruxelles, Editions de l'Université de Bruxelles.

Clinton, R., (2019). Crises, cultural identities and the development of Africa in the 21st century. Les cahiers du CELHTO, $n^{\circ} 003$. 
Cottin, J. (2001). Le sacré dans la publicité: Autres Temps; Cahiers d'éthique sociale et politique. $N^{\circ} 69$.

Creswell, J., (2009). Research Design: Qualitative, Quantitative, and Mixed Methods Approaches. University of Nebraska-Lincoln; by Sage Publications.

Debord, G., (1973). La société du spectacle - partie 1 - vidéo 45 mn.

Dobzhansky, G. (1966). Heredity and the Nature of Man.

Domenjoz, J-C, 1998. L'approche sémiologique, Free pdf 26p.

Gabrielle, A-S., \& Molho, J. (2015). Beyond Soft Power: European Journal of Turkish Studies (Social Sciences on Contemporary Turkey.

Galisson, R. (1991). De la langue à la culture par les mots. Paris: CLE International, Col. Didactique des langues étrangères.

González, O., (2009). Culture and Politics in the Visual Arts of the Occupied Palestinian Territories. Journal article.

Hall, T., (1977). Beyond Culture; Anchor Books Edition.

Hénault, A., (2008). Image et texte au regard de la sémiotique; Armand Colin; Vol $2 n^{\circ} 161$.

Huberman, M., \& Miles, B., (1984). Qualitative Data Analysis; Beverly Hills.

Herskovits, M. (1967). Culture - Société; Les Bases de l'anthropologie culturelle, (English: Basics of cultural anthropology). Paris, Payot.

Jost F., (2007). Ruptures et retournements de la sémiologie des médias à l'ère de la communication ; texte intégral Pdf.

Lacey, N., (2009). Image and Representation: Key concepts in media studies.

Lefebvre, M., (2016). Présentation de «Théorie de la communication versus structuralisme» de C. Metz, in « Mise au Point».

Metz, C., (1978). Théorie de la communication versus structuralisme ; texte intégral Pdf.

Quivy, R., \& Campenhoudt V., (1995). Social Sciences Research Manual, Paris, Dunod.

Saussure, F., (1968-1974). Cours de linguistique générale. Edition critique par R. Engler, Wiesbaden, Harrassowitz.

Schramm, W. (1954). How communication works. In W. Schramm (Ed.); The process and effects of mass communication. Urbana, IL: University of Illinois Press. 
Warren, A. Ault, P., Emery, E., (1989). Introduction to Mass-Communications. Edition De Boeck.

Witt, E., (2017). Nollywood: The Making of a Film Empire. Paperback - October 17.

Wolton, D. (1997). Penser la communication, Edition Hermes, Paris. 